\title{
Research on Professional Core Competence of Ability-oriented Professional Talent in International Economic \& Trade under the Background of "Internet $+"$
}

\author{
Rong Wang ${ }^{1, a, *}$ \\ ${ }^{1}$ Changchun Guanghua College, changchun 130033, China \\ a374650147@qq.com \\ *corresponding author
}

Keywords: Internet +; the Belt and Road; Professional Core Competencies; Ability to Operate Foreign Trade; Intercultural Communication and Communication Skills; Ability to Operate CrossBorder E-Commerce; International Perspectives.

\begin{abstract}
This article illustrates the changes of the trade patterns, trade rules and trade subjects of international trade under the background of "Internet + ". With these changes, the needs of international economic and trade professions have also changed. According to the characteristics of international trade professions under the background of "Internet +", this paper proposes that the four major core competencies that international economic and trade talents should possess are respectively: foreign trade operational capacity, cross-cultural communication and communication skills, cross-border e-commerce operating capabilities and international perspective capability. The international economic and trade talents with these four professional core competencies can grasp and make use of the Internet tools for cross-border electronic trade and better promote the development of China's foreign trade.
\end{abstract}

\section{International Trade under the Background of "Internet +"}

In 2015, Premier Li Keqiang first proposed the concept of "Internet +" in the "Report on the Work of the Government" of the NPC and CPPCC National Committee and proposed the formulation of an "Internet $+"$ plan of action. From then on, all traditional industries in China started to utilize Internet platform technology, and based on Internet development and integration, the traditional industries have rejuvenated many new business models. Since the "Internet +" plan of action has been put forward, "Internet +" has affected and transformed many industries in our country. At present, we often refer to cross-border e-commerce, Internet finance, online film and television, Internet agriculture and Internet healthcare which are the impact result of "Internet + ".

Under the background of "Internet +", profound changes have taken place in many aspects of international trade, and trade patterns, trade rules and trade subjects have been changed in international trade.

Under the background of "Internet +", the way of international trade is different from that of traditional trade. The traditional way of trade is mainly through trade negotiations between the two parties. However, the international trade in the context of "Internet + " is based on the Internet Trading and transmission of trade, that is, whether it is trade in goods or services, are through the Internet, through the wired and wireless digital network transmission and trading of products or services, in short, is what we now often refer to cross-border electronic Business. With the advancement of Internet technology, cross-border consumption, cross-border purchases, crossborder logistics and cross-border payments are all realized through cross-border e-commerce platforms. As a result, international trade has broken through various obstacles among various countries and achieved without border trade, this mode of operation is different from the traditional one-way logistics-oriented mode of operation, which realizes a new trade mode integrating information flow, commodity flow, capital flow and logistics.

With the advantage of this new mode of trade, the traditional trade rules can not fully meet the 
needs of current trade development. Some new trade rules should be formulated to promote the further development of international trade. With the development of cross-border e-commerce, which makes international trade easier and easier, more small, medium-sized micro-enterprises and even individuals can engage in international trade. Therefore, to establish the global trade rules for cross-border e-commerce, we must establish an Internet security review Rules, so that there are rules, when there is a trade dispute can be judged according to the rules, which is conducive to the development of international trade.

Under the "Internet +" background, the main body of trade in international trade is also changing. In recent years, with the development of cross-border e-commerce, the number of small businesses and individuals involved in international trade has been on the rise. Compared with the traditional trade, characteristics of international trade is small amount of trade, high frequency and fragmentation, and payment and settlement methods of international trade are also different from traditional trade. It is also important to regulate such small trade.

At present, China's cross-border trade in e-commerce communications technology, industrial environment, policies and laws are maturing, and certain scale of industrial clusters and transactions have been formed. With the implementation of the "Belt and Road ", cross-border e-commerce will become an important form of international trade and global economic cooperation. In 2016, the cross-border e-commerce transaction volume in China was 6.7 trillion yuan, an increase of $24 \%$ over the same period of last year. According to the "2017 (top) China e-commerce market data monitoring report" released by China Electronic Commerce Research Center, The volume of border e-commerce transactions was 3.6 trillion yuan, up 30.7\% over the same period of last year. The import and export of cross-border e-commerce has become a new growth point for China's foreign trade.

\section{The Characteristics of Demand for International Economic and Trade Talents under the Background of "Internet +"}

Under the background of "Internet +", there have been new changes in the demand characteristics of international economic and trade talents. Traditional international trade is mainly trade between enterprises and enterprises. However, under the background of "Internet +", with the development of Internet technologies, especially the "the Belt and Road" strategy in China, the development of cross-border e-commerce in China has been implemented walking in the forefront of the world, so in the future our country's demand for international trade talents will be expanded.

In the context of "Internet +", cross-border e-commerce is a new mode of trade in international trade. Such Internet-based and information technology applications will bring about tremendous market changes and changes in the trading business operations. Such changes have also affected demand for the international economy and trade talents.

When international trade enters the era of "Internet +", talents in the field of international economy and trade should be composite cross-border e-commerce talents with an integrated knowledge system. They should not only understand international trade knowledge but also know cross-border e-commerce knowledge, at the same time they also have to keep learning ability, and are willing to accept and try new things. Because of the development of cross-border e-commerce, new knowledge, new concepts will emerge in an endless stream, so they need continuous learning.

Under the "Internet + " background, one of the most prominent features of cross-border ecommerce is the liberation of tens of thousands of SMEs. It has pushed these SMEs and selfemployed operators from the marginalization of international trade to the center of the trade arena, making them an active participant in international trade. Countries along the "Belt and Road" can give full play to the low cost and high efficiency of cross-border electricity suppliers, cultivate more SMEs to enter here and participate in international trade so as to form an "online silk road" with smooth trade.

With the development of the "One Belt and One Road" strategy, there will be tremendous demand for cross-border e-commerce talents in all countries and regions in the world, especially in the countries and regions along the "Belt and Road". Cross-border e-commerce platform in Alibaba 
has a large number of online transactions in more than 50 countries and regions directly relating to the "One Belt and One Road" project. The demand for cross-border e-commerce professionals has already begun to emerge.

\section{The professional core competencies of competency-oriented international economic and trade talents under the background of "Internet +"}

At present, the impact of "Internet+ foreign trade" on China's foreign trade is growing. However, most of the international economics and trade majors in higher education schools in our country still fail to recognize this issue. The rapid development of cross-border e-commerce in our country has become a new profit growth point of foreign trade enterprises. Faced with the new trend of the flourishing development of cross-border e-commerce, the traditional teaching of international trade in our country is facing great challenge. The major of international economy and trade should carry out the capacity-oriented reform of the training mode of international economic and trade talents and reformulate the training programs for international trade talents so that the students who are trained in this field can master and make use of the Internet for cross-border e-commerce, Better promote the development of China's foreign trade.

According to the characteristics of the demand of international trade talents under the background of "Internet + ", the four major professional core competencies that the international economic and trade talents should have are: foreign trade operational ability, cross-cultural communication and communication skills, cross-border e-commerce operation Competence and international perspective capability.

Foreign trade operational ability is to determine whether a person has the core competencies of foreign trade work. Students are required to acquire the negotiation skills in international trade, grasp the writing of trade correspondence, grasp the accounting of the import and export commodity prices, and master the basic process of import and export trade through professional study combining with the actual conditions in our country and international trade practices. Various trade terms and a variety of international settlement methods, to master the import and export goods shipping and booking, reporting for test, customs declaration, all kinds of documents such as the production and audit of the major business skills.

Intercultural communication and communication skills in international trade mainly refer to the friendly communication and communication between trading partners who can speak English and have different cultural backgrounds. International students majoring in economy and trade need to know the language, culture and history of their own country. They also need to know other languages, cultures, and histories. Since international trade is a trade with all countries in the world, it is necessary to have effective cross-cultural exchange and communication in order to achieve a win-win result for both sides through smooth and fair trade cooperation.

The ability to operate cross-border e-commerce is the ability to understand both international trade and e-commerce and make use of various e-commerce technologies to conduct international trade. Cross-border e-commerce is the use of the Internet and information technology to promote globalization of trade and to move international trade toward borderless trade. Whether for enterprises or individuals, the use of cross-border e-commerce platform can carry out multidimensional and three-dimensional trade and broaden the path to international markets, greatly promoting the optimal allocation of world resources and mutual benefits among enterprises.

International vision means that in conducting international trade, it should have a globalized vision, and should not look beyond the limits of one country or region. Instead, to consider the world as a market without being limited to the domestic market or foreign points, so as to seize more markets and trade opportunities. An international perspective means, in the first place, the world is thought to be pluralistic in its thinking. Those engaged in international trade need to have multiple perspectives and various forms of management. International economics and trade major should cultivate students' global vision. They need to know their own national culture, but also understand and appreciate other cultures without blind imitation and admirers of other cultures and cultivate a truly international vision. 


\section{Acknowledgements}

This work was financially supported by Key Issues in Teaching Reform of Higher Education in Jilin Province in 2016 (Capacity-oriented Reform and Practice in International Economy and Trade Professionals Training Mode under the Background of "Internet Plus") fund; Education Science Planning Project of Jilin Province in 2016 (Under the Strategy of "Belt and Road" Jilin province cross-border e-commerce talent cultivation research; subject number GH16570) fund.

\section{References}

[1] Zhang Dejiang; Kang Qipeng; Li Wenguo; Yu Shuhan; Wang Yulan. Private university transformation and development: what turn, how to turn [J]. Modern Education Science .2015 (11).

[2] Wei Gekun. Local colleges and universities "Internet + Foreign Trade, innovative and practical personnel training difficulties analysis [J]. Higher Education Edition .2016 (05).

[3] Liang Liping. Research on innovative reform of international economy and trade specialty based on "Internet +" thinking [J] .Journal of Shandong Agricultural Engineering Institute .2016 (05). 